Volume. 8 Nomor. 1, Oktober 2020. p - 2354-8649 I e - 2579-5767

Open Access at: http://ojs.umrah.ac.id/index.php/selat

DOI: https://doi.org/10.31629/selat.v8i1.2747

\title{
PENEGAKAN HUKUM TINDAK PIDANA CUKAI DI PERBATASAN KAWASAN PERDAGANGAN DAN PELABUHAN BEBAS BINTAN
}

\author{
Irwandi Syahputra1, Elwi Danil2, Oksep Adhayanto ${ }^{3}$, Ayu Efritadewi ${ }^{4}$ \\ 1,3,4Program Studi Ilmu Hukum, Fakultas Ilmu Sosial dan Ilmu Politik \\ Universitas Maritim Raja Ali Haji, Jalan Raya Dompak, Tanjungpinang, Kepulauan Riau 29100 \\ ${ }^{2}$ Fakultas Hukum Universitas Andalas, Jl. Pancasila No. 10 Padang, Sumatera Barat, 25117 \\ irwandisyahputra94@gmail.com
}

\begin{abstract}
Part of the Tanjungpinang area is a free trade area and a free port. Placing some of these areas makes it difficult to supervise the traffic of goods, especially the excisable goods of the type of cigarettes, plus in the case of law enforcement, none of these excise crimes have been brought to court. Bintan free port. The method used in this research is sociological juridical method. Or what is known as empirical. Based on this research, it can be concluded that in law enforcement, the imposition of sanctions must pay attention to several things that become one unit, namely people's ignorance of the prohibited items, the number of items in a small number and not a repetition of the same criminal act. The granting of excise exemption quotas for excisable goods types of cigarettes for public consumption must be taken into account of the urgency of this.
\end{abstract}

Keywords; Law Enforcement, Excise Crime, Free Zone.

\begin{abstract}
Abstrak
Sebagian wilayah Tanjungpinang merupakan kawasann perdagangan bebas dan pelabuhan bebas. Menempatkan sebagian wilayah tersebut mengakibatkan sulitnya melakukan pengawasan terhadap lalu lintas barang terutama barang kena cukai jenis rokok ditambah dalam hal penegakan hukum tindak pidana cukai tersebut belum ada yang di sampai kepengadilan. Rumusan masalah dalam penelitian ini yaitu bagaimana penegakan hukum tindak pidana cukai di perbatasan kawasan perdagangan dan pelabuhan bebas bintan. Metode yang digunakan dalam penelitian ini adalah metode yuridis Sosiologis. Atau yang dikenal dengan empiris. Berdasarkan penelitian ini dapat disimpulkan dalam penegakan hukum pemberian sanksi tindakan harus memperhatikan beberapa hal yang menjadi satu kesatuan yaitu ketidaktahuan orang akan barang yang dilarang, jumlah barang dalam hitungan sedikit dan bukan merupakan pengulangan tindak pidana yang sama. Pemberian kuota pembebasan cukai terhadap barang kena cukai jenis rokok untuk konsumsi masyarakat harus dijadikan pertimbangan terhadap urgensi hal tersebut.
\end{abstract}

Kata Kunci; Penegakan Hukum, Tindak Pidana Cukai, Kawasan Bebas. 


\section{PENDAHULUAN}

Manusia memiliki kehendak untuk memenuhi kebutuhan hidupnya, kehendak tersebut diwujudkan dalam bidang ekonomi yaitu bekerja dan berusaha untuk kelangsungan hidupnya. Perdagangan merupakan hal yang sering dilakukan oleh manusia baik itu dalam skala kecil, menengah maupun lingkup yang lebih besar. Sehingga negara hadir untuk mengatur segala aktifitas tersebut demi terwujudnya kesejahteraan masyarakat dan sebagai penjaga aktifitas tersebut dari praktik-praktik ilegal yang cendrung akan merusak sistem ekonomi masyarakat.

Kegiatan perdagangan dapat dilakukan dalam 2 (dua) bentuk yaitu ekspor dan impor. Berdasarkan Undang-Undang Republik Indonesia Nomor 17 Tahun 2006 Perubahan Atas Undang-Undang Nomor 10 Tahun 1995 tentang Kepabenan dalam pasal 1 menjelaskan bahwa ekspor adalah kegiatan mengeluarkan barang dari daerah pabean dan impor adalah kegiatan memasukkan barang ke dalam daerah pabean. Kedua kegiatan tersebut dikenakan bea masuk atau keluar dalam bentuk pungutan negara. Sehingga pengawasan atas lalu lintas barang tersebut tunduk kepada Undang-Undang Kepabeanan.

Barang-barang yang memiliki karakteristik tertentu tunduk kepada pemberlakukan Undang-Undang Cukai. Meskipun Undang-Undang Kepabeanan dan Cukai memiliki kesamaan yaitu pengaturan terhadap lalu lintas barang, namun Undang-Undang Cukai memiliki kekhususan terhadap barang-barang tertentu seperti hasil tembakau, minuman mengandung etil alkohol dan barang yang memiliki kandungan etil alkohol atau etanol. Karakteristik barang kena cukai termuat dalam Pasal 2 Undang-Undang Republik Indonesia Nomor 39 Tahun 2007 Tentang Perubahan Atas Undang-Undang Nomor 11 Tahun 1995 Tentang Cukai yang menjelaskan bahwa barang-barang tertentu yang mempunyai sifat atau karakteristik barang kena cukai adalah barang tertentu yang konsumsinya perlu dikendalikan, barang tertentu yang peredarannya perlu diawasi, barang tertentu yang pemakaian dapat menimbulkan dampak negatif bagi masyarakat atau lingkungan hidup dan pemakaiannya perlu pembebanan pungutan negara demi keadilan serta keseimbangan.

Ketentuan menimbang dalam Undang-Undang Republik Indonesia Nomor 36 Tahun 2000 Tentang Penetapan Peraturan Pemerintah Pengganti Undang-Undang 
Nomor 1 Tahun 2000 Tentang Kawasan Perdagangan Bebas Dan Pelabuhan Bebas pada huruf (c) menguraikan bahwa suatu daerah perdagangan dan pelabuhan bebas dapat mendorong kegiatan lalu lintas perdagangan internasional yang mendatangkan devisa bagi negara serta dapat memberi pengaruh dan manfaat besar bagi indonesia, untuk dapat membuka lapangan kerja seluas-luasnya, meningkatkan kepariwisataan dan penanaman modal baik asing maupun dalam negeri. Kawasan Perdagangan Bebas dan Pelabuhan Bebas adalah suatu kawasan yang berada dalam wilayah hukum Negara Kesatuan Republik Indonesia yang terpisah dari daerah pabean sehingga bebas dari pengenaan bea masuk, pajak pertambahan nilai, pajak penjualan atas barang mewah dan cukai. ${ }^{1}$

Di Indonesia Kawasan Perdagangan Bebas dan Pelabuhan Bebas hanya diberikan kepada 4 (empat) daerah yaitu Provinsi Nanggroe Aceh Darussalam terhadap wilayah Sabang dan 3 (tiga) lagi di wilayah Provinsi Kepulauan Riau diantaranya yaitu Batam, Bintan dan Karimun. ${ }^{2}$ Batas-batas Kawasan Perdagangan Bebas dan Pelabuhan Bebas Kepulauan Riau termuat dalam Peraturan Pemerintah Nomor 46 Tahun 2007, Peraturan Pemerintah Nomor 47 tahun 2007 dan Peraturan Pemerintah Nomor 48 Tahun 2007.

Pasal 1 ayat (2) Peraturan Pemerintah Republik Indonesia Nomor 41 Tahun 2017 Tentang Perubahan Atas Peraturan Pemerintah Nomor 47 Tahun 2007 Tentang Kawasan Perdagangan Bebas Dan Pelabuhan Bebas Bintan. menetapkan kawasan perdagangan bebas dan pelabuhan bebas Bintan meliputi sebagian dari wilayah Kabupaten Bintan dan sebagian dari wilayah Kawasan Industri Galang Batang, serta seluruh Kawasan Industri Maritim, Pulau Lobam dan sebagian dari wilayah Kota Tanjungpinang yang meliputi Kawasan Industri Senggarang dan Kawasan Industri Dompak Darat. Peraturan tersebut menimbulkan permasalahan secara teknis dikarenakan penempatkan sebagian wilayah Kota Tanjungpinang sebagai bagian dari Kawasan Perdagangan Bebas Dan Pelabuhan Bebas Bintan sehingga akan menyulitkan dalam pengawasan barang-barang yang beredar.

Di wilayah Kota Tanjungpinang peredaran ilegal hasil tembakau menggunakan

\footnotetext{
1 Pasal 1 Peraturan Pemerintah Pengganti Undang-Undang Nomor 1 Tahun 2000 Tentang Kawasan Perdagangan Bebas dan Pelabuhan Bebas.

2 Wawancara dengan Den Yealta, Kepala Badan Pengusahaan Pelayanan Terpadu Satu Pintu (PTSP) Free Trade Zone Tanjungpinang, Hari Senin, Tanggal 10 Juli 2017.
} 
beberapa modus operandi diantaranya yaitu peredaran rokok polos tanpa cukai dan peredaran rokok yang peruntukannya hanya untuk kawasan bebas (Free Trade Zone) yang jalur masuknya melalui pelabuhan-pelabuhan begitu juga terhadap peredaran minuman alkohol golongan tertentu yang tanpa di lekati pita cukai. ${ }^{3}$ Berdasarkan data yang di peroleh dari Antara News, bahwa minuman beralkohol golongan A buatan dalam negeri yang seharusnya beredar terbatas di Kawasan Perdagangan Bebas dan Pelabuhan Bebas Batam, Bintan dan Karimun ternyata dijual di toko dan swalayan di tanjungpinang. ${ }^{4}$ Hasil tembakau, minuman alkohol dan etil alkohol kawasan bebas mutlak hanya dikonsumsi dikawasan bebas dan tidak boleh dijual diluar kawasan bebas. ${ }^{5}$

Peredaran barang kena cukai atau rokok kawasan bebas (Free Trade Zone) jika dijual di luar wilayah peruntukannya maka akan tunduk kepada ketentuan UndangUndang Cukai dalam Pasal 54 dan Pasal 56 Undang-Undang Nomor 39 Tahun 2007 Tentang Perubahan Atas Undang-Undang Nomor 11 Tahun 1995 Tentang Cukai dengan ancaman pidana penjara paling singkat 1 (satu) tahun dan paling lama 5 (lima) tahun dan pidana denda paling sedikit 2 (dua) kali nilai cukai dan paling banyak 10 (sepuluh) kali nilai cukai yang seharusnya dibayar. Terhadap barang kena cukai atau rokok kawasan bebas (Free Trade Zone) yang ditangani Bea dan Cukai Tanjungpinang belum ada yang sampai kepada proses peradilan. ${ }^{6}$

\section{METODE PENELITIAN}

Penelitian pada dasarnya merupakan tahapan untuk mencari kembali sebuah kebenaran. Sehingga akan dapat menjawab pertanyaan-pertanyaan yang muncul tentang suatu objek penelitian. ${ }^{7}$ Metode penelitian yang akan dilakukan oleh penulis adalah penelitian yuridis empiris yaitu penelitian hukum yang dikonsepkan sebagai pranata sosial secara empiris yang berdasarkan data sekunder sebagai data awal

\footnotetext{
3 Wawancara dengan Jatmiko, Bagian Penyuluhan dan Layanan Informasi Kantor Pengawasan dan Pelayanan Bea dan Cukai (KPPBC) Tipe Madya Pabean B Kota Tanjungpinang, Hari Selasa, Tanggal 15 September 2015.

4 Kepri.antaranews.com. "Minuman Beralkohol Kawasan Bebas Beredar Di Tanjungpinang," https://kepri.antaranews.com/berita/16172/minuman-beralkohol-kawasan-bebas-beredar-di-tanjungpinang. Terakhir dikunjungi pada tanggal 21 November 2017, Jam 14.20

5 Wawancara dengan Jatmiko, Bagian Penyuluhan dan Layanan Informasi Kantor Pengawasan dan Pelayanan Bea dan Cukai (KPPBC) Tipe Madya Pabean B Kota Tanjungpinang, Hari Selasa, Tanggal 15 September 2015.

6 Wawancara dengan Jatmiko, Bagian Penyuluhan dan Layanan Informasi Kantor Pengawasan dan Pelayanan Bea dan Cukai (KPPBC) Tipe Madya Pabean B Kota Tanjungpinang, Hari Selasa, Tanggal 15 September 2015.

7 Bambang Sunggono, Metode Penelitian Hukum (Jakarta: Raja Grafindo Persada, 2001), hlm. 29.
} 
kemudian dilanjutkan dengan data primer atau data yang diperoleh dari lapangan. ${ }^{8}$ Penelitian hukum empiris dapat disebut juga dengan penelitian sosiologis yang mana penelitian ini mengkaji antara fenomena hukum yang terjadi di masyarakat dan dengan apa yang di kehendaki oleh Peraturan Perundang-undangan serta teori-teori hukum.

\section{PEMBAHASAN}

Penegakan Hukum adalah proses dilakukannya upaya untuk tegaknya atau berfungsinya norma-norma hukum secara nyata sebagai pedoman perilaku dalam lalu lintas atau hubungan-hubungan hukum dalam kehidupan bermasyarakat dan bernegara. ${ }^{9}$ Sehingga hukum merupakan sandaran berperilaku kearah yang positif sebagaimana yang di kehendak pembentuk Undang-undang atau Negara. Ketentuan materil dalam undang-undang merupakan debu jika tidak ada hukum formil yang mengatur sebagai panglima penegak hukum materil. Namun bukan berarti setelah ada hukum formil akan baik-baik saja harus juga di dukung penuh oleh kekuatankekuatan struktur hukum, substansi hukum dan budaya hukum. Lebih luas menurut Soerjono Soekanto penegakan hukum (law enforcement) menghendaki empat syarat, yaitu : adanya aturan, adanya lembaga yang akan menjalankan peraturan itu, adanya fasilitas untuk mendukung pelaksanaan peraturan itu, adanya kesadaran hukum dari masyarakat yang terkena peraturan itu. ${ }^{10}$

Penegakan hukum memiliki kaitan yang erat dengan penerapan hukum. Jika hukum sudah diterapkan dengan sebagaimana mestinya maka penegakan hukum sudah terlaksanakan. Penerapan hukum di dalam masyarakat sesungguhnya tidak sesederhana ketika hukum selesai dibuat, kemudian apakah hukum tersebut langsung dapat diterapkan. Hukum sebagai sesuatu yang akan bersinggungan langsung dengan masyarakat, jelas akan banyak bergelut dengan sekian banyak dimensi dan faktor yang hidup di dalam masyarakat. Tidak jarang terjadi produk hukum yang ada tidak sesuai dengan kondisi sosial, ekonomi dan politik

\footnotetext{
${ }^{8}$ Amiruddin and Zainal Asikin, Pengantar Metode Penelitian Hukum (Jakarta: Raja Grafindo Persada, 2003), hlm. 132.

${ }_{9}^{9}$ Purnadi Purbacaraka, Penegakan Hukum Dalam Mensukseskan Pembangunan, Alumni, Bandung, 1977, hlm. 77.

10 Soerjono Soekanto, Pendekatan Sosiologi Terhadap Hukum, Bina Aksara, Jakarta: 1987, hlm. 9.
} 
masyarakat. ${ }^{11}$

Tugas dan Fungsi PPNS Bea dan Cukai sangat besar dalam menjaga dan mengamankan keuangan negara dari praktik-praktik tindak pidana penyelundupan. Karena salah satu pendapatan besar negara Indonesia adalah penerimaan bea masuk, bea keluar, dan cukai, disinilah peran PPNS Bea dan Cukai untuk menjaga keuangan negara dan mengawasi segala kegiatan yang berkaitan dengan Kepabeanan dan Cukai misalnya kegiatan ekspor, impor, pembayaran cukai, dan fasilitas. ${ }^{12}$ Tugas Bea dan Cukai semakin besar jika berhadapan dengan pengawasan dan penindakan terhadap batas-batas lalu lintas di kawasan perdagangan bebas dan pelabuhan bebas.

Penindakan terhadap barang dan/ atau sarana pengangkut serta bangunan atau tempat lain adalah suatu wewenang kepabeanan yang bersifat administratif dalam rangka menjamin hak-hak negara dan dipatuhinya ketentuan larangan dan pembatasan. Disadari bahwa penindakan tersebut tentunya akan menghambat kelancaran arus barang dan mengakibatkan keadaan yang kurang memuaskan bagi pemiliknya. Oleh karena itu, dalam pelaksanaannya dituntut kesadaran yang tinggi berdasarkan persyaratan yang ditetapkan dan bersifat objektif. Pejabat Bea dan Cukai yang akan melaksanakan penindakan harus telah mempunyai petunjuk yang cukup atas tindakan yang akan diambilnya dan tetap mengutamakan tingkat pelayanan yang tinggi serta memberikan kepastian bagi pemilik barang dan orang yang dikenakan penindakan. ${ }^{13}$

Penerapan hukum materil dalam undang-undang cukai memiliki tantangan yang amat besar jika wilayah tertentu dalam wilayah Negara Kesatuan Republik Indonesia bersanding dengan Kawasan Perdagangan dan Pelabuhan Bebas (Free Trade Zone) yang mana secara undang-undang di pisahkan dari daerah pabean. Pemisahan dari daerah pabean tersebut berimplikasi terhadap barang-barang yang bebas dari pengenaan bea masuk, pajak pertambahan nilai, pajak penjualan atas barang mewah dan cukai akan mudah masuk ke wilayah yang bukan peruntukannya terutama barang kena cukai atau rokok. Berikut ini adalah hasil tangkapan rokok

11 Eddi Wibowo, dkk, Hukum dan Kebijakan Publik, Yayasan Pembaruan Administrasi Publik Indonesia, Yogyakarta: 2004, hlm. 8.

12 Jessica E. Saroinsong, "Peran Penyidik Pegawai Negeri Sipil (PPNS) dalam Tindak Pidana Bea dan Cukai Menurut Undang-Undang No. 17 Tahun 2006 Tentang Kepabeanan dalam Kasus Penyelundupan," Lex Et Societatis, Vol. VII, No. 7 (2019), hlm. 37.

13 Milyan Risydan Al Anshori, "Penguatan Bea Cukai Secara Kelembagaan Dalam Menghadapi Kejahatan Transnasional," Jurnal Ilmiah Dunia Hukum, Vol. 1, No. 1 (2016), hlm. 52. 
illegal oleh Kantor Pengawasan dan Pelayanan Bea dan Cukai Tipe Madya Pabean B Kota Tanjungpinang yang dapat diuraikan dalam tabel berikut ini:

Tabel 1

Data Hasil Tangkapan Rokok Ilegal di Kota Tanjungpinang 2016 s/d Mei 2020

\begin{tabular}{|c|c|c|c|}
\hline No & Tahun & $\begin{array}{c}\text { Jumlah Tangkapan Rokok } \\
\text { Ilegal (Batang) }\end{array}$ & $\begin{array}{c}\text { Surat Bukti } \\
\text { Penangkapan } \\
\text { (SBP) }\end{array}$ \\
\hline 1 & 2016 & 1.363 .232 & 12 \\
\hline 2 & 2017 & 811.029 & 80 \\
\hline 3 & 2018 & 5.087 .544 & 47 \\
\hline 4 & 2019 & 3.400 .000 & 72 \\
\hline 5 & 2020 & 938.008 & 38 \\
\hline
\end{tabular}

Sumber: Kantor Pengawasan dan Pelayanan Bea dan Cukai Tipe Madya Pabean B Kota Tanjungpinang

Berdasarkan tabel diatas dapat diuraikan bahwa jumlah tangkapan Rokok Ilegal dan jumlah surat bukti penangkapan cukup menunjukkan angka yang tinggi. Berdasarkan Peraturan Pemerintah Republik Indonesia Nomor 41 Tahun 2017 Tentang Perubahan Atas Peraturan Pemerintah Nomor 47 Tahun 2007 Tentang Kawasan Perdagangan Bebas Dan Pelabuhan Bebas Bintan menempatkan sebagian wilayah Tanjungpinang sebagai wilayah Free Trade Zone yaitu kawasan industri Senggarang dan kawasan Industri Dompak Darat. Sehingga barang kena cukai yang hanya peruntukkan wilayah tersebut akan lebih mudah beredar ke wilayah-wilayah terdekat yang bukan wilayah peruntukannya.

Pemasukan dan pengeluaran barang ke dan dari Kawasan Perdagangan Bebas dan Pelabuhan Bebas hanya dapat dilakukan oleh pengusaha yang telah mendapat izin usaha dari Badan Pengusahaan. Pengusaha hanya dapat memasukkan barang ke Kawasan Perdagangan Bebas dan Pelabuhan Bebas yang berhubungan dengan kegiatan usahanya dan pemasukan barang konsumsi untuk kebutuhan penduduk kawasan bebas dengan jumlah dan jenis barang yang diberikan fasilitas ditetapkan oleh Badan Pengusahaan. ${ }^{14}$ Aturan yang jelas mengatur berkaitan dengan pemasukan dan pengeluaran barang oleh pengusaha pun telah diatur secara jelas. Sehingga

14 Wawancara dengan Muhammmad Effendi, Bidang Penyuluhan dan Pelayanan Perizinan Badan Pengusahaan Kawasan Perdagangan Bebas Dan Pelabuhan Bebas Bintan Wilayah Kota Tanjungpinang, Hari Selasa, Tanggal 6 Maret 2018. 
praktik-praktik yang ilegal oleh setiap orang diluar dari pengusaha tersebut sudah jelas hal yang sangat bertentangan dengan Peraturan Perundang-undangan baik itu dalam aturan tentang kawasan bebas maupun aturan tentang cukai.

Berdasarkan penelitian tesis penulis terdahulu ada beberapa hal poin penting yang akan dijelaskan dalam tulisan ini yaitu berkaitan dengan faktor yang mempengaruhi penegakan hukum tindak pidana cukai di perbatasan kawasan bebas dan pelabuhan bebas Bintan yaitu:

1. Menempatkan sebagian wilayah Kota Tanjungpinang sebagai Kawasan Perdagangan dan Pelabuhan Bebas Bintan (Enclave)

Peraturan Pemerintah Republik Indonesia Nomor 47 Tahun 2007 Tentang Kawasan Perdagangan Bebas Dan Pelabuhan Bebas Bintan sebagaimana yang telah diperbaharui dengan Peraturan Pemerintah Republik Indonesia Nomor 41 Tahun 2017 menetapkan kawasan perdagangan bebas dan pelabuhan bebas Bintan meliputi:

a. Sebagian dari wilayah Kabupaten Bintan dan sebagian dari wilayah Kawasan Industri Galang Batang, serta seluruh Kawasan Industri Maritim, dan Pulau Lobam.

b. Sebagian dari wilayah Kota Tanjungpinang yang meliputi Kawasan Industri Senggarang dan Kawasan Industri Dompak Darat.

Kawasan perdagangan bebas dan pelabuhan bebas di kawasan industri Senggarang ditetapkan dengan luas \pm 1333 Hektar dan di kawasan industri Dompak Darat seluas \pm 1300 Hektar. Pengembangan kegiatan-kegiatan di bidang ekonomi didalam Kawasan Perdagangan Bebas dan Pelabuhan Bebas dilakukan sesuai dengan Rencana Tata Ruang Wilayah Kota Tanjungpinang. ${ }^{15}$

2. Perbandingan kuota Barang Kena Cukai dengan jumlah penduduk kawasan bebas dan relevansinya dengan kebutuhan wajar.

Barang kena cukai yang digunakan untuk kebutuhan konsumsi penduduk di Kawasan Bebas wajib mencantumkan tulisan "Khusus Kawasan Bebas" disertai dengan penyebutan wilayah kawasan bebas tempat peredaran barang kena

15 Wawancara dengan Pamri, Anggota 1 Bidang Administrasi dan Penyusunan Program Badan Pengusahaan Kawasan Perdagangan Bebas Dan Pelabuhan Bebas Bintan Wilayah Kota Tanjungpinang, Hari Senin, Tanggal 12 Februari 2018. 
cukai. ${ }^{16}$ Jumlah dan jenis barang kena cukai yang telah dikeluarkan oleh Badan Pengusahaan Kawasan Kota Tanjungpinang baru kepada jenis barang kena cukai hasil tembakau berupa Rokok, jumlah kuota yang dikeluarkan tersebut diuraikan dalam tabel dibawah ini :

Tabel. 2

Jumlah Kuota Pendistribusian Hasil Tembakau Khusus Kawasan Bebas Februari 2017 Wilayah Kota Tanjungpinang

\begin{tabular}{|c|c|c|}
\hline No & Nama Perusahaan & Jumlah Kouta \\
\hline 1 & CV Three Star Bintan & 1.400 karton \\
\hline 2 & PT Bintan Aroma Sejahtera & 9.400 karton \\
\hline 3 & PT Sarana Dompak Jaya & 600 karton \\
\hline 4 & PT Pratama Dompak Karya & 1.744 karton \\
\hline 5 & PT Bintan Adikarya Jaya & 400 karton \\
\hline 6 & PT Megatama Pinang Abadi & 5.300 karton \\
\hline & Jumlah Total & 18.844 karton \\
\hline
\end{tabular}

Sumber: Batampos.co.id, Senin, 20 Maret 2017

Pabrik hasil tembakau belum ada yang berdiri di Kota Tanjungpinang sehingga semua hasil tembakau untuk konsumsi penduduk kawasan bebas di masukkan dari Pabrik di tempat lain dalam Daerah Pabean dan dari kawasan bebas lainnya seperti Batam yang telah memiliki pabrik hasil tembakau sendiri. ${ }^{17}$ Jumlah dan jenis barang kena cukai yang dimasukkan di Kawasan Bebas ditetapkan oleh Badan Pengusahaan Kawasan jika dilihat berdasarkan amanat dalam Peraturan Menteri Keuangan Nomor 47/PMK.04/2012 yaitu dibuat dengan mempertimbangkan jumlah kebutuhan secara wajar. ${ }^{18}$ Jika dilihat jumlah Penduduk Kawasan bebas wilayah Kota Tanjungpinang sebagai berikut ini :

16 Wawancara dengan Pamri, Anggota 1 Bidang Administrasi dan Penyusunan Program Badan Pengusahaan Kawasan Perdagangan Bebas Dan Pelabuhan Bebas Bintan Wilayah Kota Tanjungpinang, Hari Senin, Tanggal 12 Februari 2018.

17 Wawancara dengan Muhammmad Effendi, Bidang Penyuluhan dan Pelayanan Perizinan Badan Pengusahaan Kawasan Perdagangan Bebas Dan Pelabuhan Bebas Bintan Wilayah Kota Tanjungpinang, Hari Senin, Tanggal 12 Februari 2018.

18 Pasal 105 ayat (2) Peraturan Menteri Keuangan Republik Indonesia Nomor 47/PMK.04/2012 Tentang Tata Laksana Pemasukan Dan Pengeluaran Barang Ke Dan Dari Kawasan Yang Telah Ditetapkan Sebagai Kawasan Perdagangan Bebas Dan Pelabuhan Bebas Dan Pembebasan Cukai. 
Tabel. 3

Jumlah Penduduk Kawasan Bebas Di Wilayah Kota Tanjungpinang Per-Desember 2017

\begin{tabular}{|c|l|c|c|c|}
\hline No & \multicolumn{1}{|c|}{$\begin{array}{c}\text { Penduduk } \\
\text { Kawasan Bebas }\end{array}$} & Laki-Laki & Perempuan & Jumlah \\
\hline 1 & Senggarang & 2170 Orang & 1985 Orang & 4155 Orang \\
\hline 2 & Dompak Darat & 654 Orang & 599 Orang & 1253 Orang \\
\hline \multicolumn{4}{|c|}{ Jumlah Keseluruhan } & 5408 Orang \\
\hline
\end{tabular}

Sumber: Kantor Kelurahan Senggarang dan Dompak

Peraturan Menteri Keuangan Republik Indonesia Nomor 120/PMK.04/2017 Tentang Perubahan Atas Peraturan Menteri Keuangan Nomor 47/PMK.04/2012 lebih memberikan secara rinci dalam Pertimbangan jumlah kebutuhan secara wajar dilakukan dengan memperhitungkan antara lain: ${ }^{19}$

a. jumlah penduduk di kawasan bebas;

b. rata-rata konsumsi barang kena cukai per hari baik yang berlabel kawasan bebas maupun tidak berlabel kawasan bebas; dan

c. angka kecenderungan merokok (prevalensi) untuk pertimbangan penetapan kuota barang kena cukai hasil tembakau.

Tiga unsur tersebut harus dipenuhi dalam penentuan jumlah kuota rokok untuk kebutuhan penduduk kawasan bebas. Pemberian kuota hasil tembakau berupa Rokok untuk kebutuhan penduduk kawasan bebas yang telah diberikan oleh Badan Pengusahaan Kawasan Wilayah Kota Tanjungpinang dalam pertimbangan jumlah kebutuhan secara wajar maka dapat diperbandingkan dengan jumlah penduduk di kawasan bebas, rata-rata konsumsi barang kena cukai per hari baik yang berlabel kawasan bebas maupun tidak berlabel kawasan bebas dan angka kecenderungan merokok (prevalensi) untuk pertimbangan penetapan kuota barang kena cukai hasil tembakau.

Rata-rata konsumsi barang kena cukai perhari dan angka kecendrungan merokok penduduk kawasan bebas dapat dilihat dari perbandingan jumlah laki-laki dan perempuan dan jumlah penduduk yang berusia 18 Tahun ke atas

19 Pasal 105 ayat (2c) Peraturan Menteri Keuangan Republik Indonesia Nomor 120/PMK.04/2017 Tentang Perubahan Atas Peraturan Menteri Keuangan Nomor 47/PMK.04/2012 Tentang Tata Laksana Pemasukan Dan Pengeluaran Barang Ke Dan Dari Kawasan Yang Telah Ditetapkan Sebagai Kawasan Perdagangan Bebas Dan Pelabuhan Bebas Dan Pembebasan Cukai 
yang mana anjuran untuk konsumen produk tembakau sebagaimana yang telah menjadi kebijakan pemerintah yaitu dapat dilihat dalam Peraturan Pemerintah yang menyatakan bahwa pada sisi samping lainnya dari Kemasan Produk Tembakau wajib dicantumkan pernyataan dilarang menjual atau memberi kepada anak berusia di bawah 18 tahun dan perempuan hamil. ${ }^{20}$ untuk mengetahui Rata-rata konsumsi barang kena cukai perhari dan angka kecendrungan merokok penduduk kawasan bebas dapat digambarkan sebagai berikut ini:

Tabel. 4

Jumlah Penduduk Kawasan Bebas Berusia 18 Tahun Ke Atas Di Wilayah Kota Tanjungpinang Per-Desember 2017

\begin{tabular}{|c|c|c|c|c|}
\hline No & $\begin{array}{c}\text { Penduduk } \\
\text { Kawasan Bebas }\end{array}$ & Laki-Laki & Perempuan & Jumlah \\
\hline 1 & Senggarang & 1587 Orang & 1464 Orang & 3051 Orang \\
\hline 2 & Dompak Darat & 428 Orang & 379 Orang & 807 Orang \\
\hline \multicolumn{4}{|c|}{ Jumlah Keseluruhan } & 3858 Orang \\
\hline
\end{tabular}

Sumber: Kantor Kelurahan Senggarang dan Dompak

Berdasarkan tabel tersebut maka dapat diperbandingkan dengan jumlah kuota hasil tembakau berupa Rokok yang di keluarkan oleh Badan Pengusahaan Kawasan Kota Tanjungpinang yaitu kuota per bulan Februari 2017 sebesar 18.844 Karton untuk perkiraan konsumsi wajar untuk 3858 Orang Penduduk Laki-Laki dan Perempuan sehingga dengan akumulasi perhitungan \pm 1 (satu) Orang 5 Karton. Tidak semua laki-laki merokok dan lazimnya hanya sedikit perempuan yang merokok. Ditambah didalam total orang tersebut ada yang berusia lanjut.

Pemberian kuota tersebut yang dikeluarkan Badan Pengusahaan Kawasan tersebut dinilai tidak sesuai atau bahkan berlebih dari semestinya. Kuota tersebut tidak megacu kepada formulasi yang ditentukan dan hanya berdasarkan asumsi. Kantor Pengawasan dan Pelayanan Bea dan Cukai Kota Tanjungpinang sudah memberikan formulasi perhitungan kuota. Namun, belum dipakai sama Badan Pengusahaan Kawasan tersebut. Sehingga Potensi

\footnotetext{
20 Pasal 21 Peraturan Pemerintah Republik Indonesia Nomor 109 Tahun 2012 Tentang Pengamanan Bahan Yang
} Mengandung Zat Adiktif Berupa Produk Tembakau Bagi Kesehatan. 
terjadinya kebocoran terkait kuota rokok di Kota Tanjungpinang pasti ada, Karena kawasan bebas di Kota Tanjungpinang hanya di dua wilayah yakni Senggarang dan Dompak Darat. ${ }^{21}$ Pembahasan Kuota yang berada di Badan Pengusahaan Kawasan menyebabkan selama ini Kantor Pengawasan dan Pelayanan Bea dan Cukai Kota Tanjungpinang belum mengatahui berapa riil jumlah kuota tersebut sehingga berpengaruh terhadap pengawasannya di daerah perbatasan dalam pabean. ${ }^{22}$

Apabila pengeluaran kuota tersebut memakai Peraturan Menteri Keuangan Nomor 147/PMK.010/2016 Tentang Perubahan Ketiga Atas Peraturan Menteri Keuangan Nomor 179/PMK.011/2012 Tentang Tarif Cukai Hasil Tembakau. Maka tidak ada permasalahan disana dikarenakan jumlah kuota tersebut sesuai dengan peraturan menteri tersebut. Namun seharusnya pemberian kuota tersebut lebih tepatnya bersandar pada Peraturan Menteri Keuangan Republik Indonesia Nomor 120/PMK.04/2017 Tentang Perubahan Atas Peraturan Menteri Keuangan Nomor 47/PMK.04/2012. yang semesti nya dibuat dengan mempertimbangkan jumlah kebutuhan secara wajar.

3. Sarana atau fasilitas pendukung

Sarana dan fasilitas yang mendukung mencakup tenaga manusia yang berpendidikan dan terampil, organisasi yang baik, peralatan yang memadai, keuangan yang cukup. Tanpa sarana dan fasilitas yang memadai, penegakan hukum tidak dapat berjalan dengan lancar dan penegak hukum tidak mungkin menjalankan peranan semestinya. ${ }^{23}$

a. Belum adanya Pelabuhan Khusus tempat pemasukan dan pengeluaran barang ke dan dari Kawasan Bebas Kota Tanjungpinang

Berdasarkan Peraturan Pemerintah Republik Indonesia Nomor 10 Tahun 2012 menetapkan bahwa pemasukan dan pengeluaran barang ke dan dari Kawasan Bebas wajib dilakukan di pelabuhan atau bandar udara yang ditunjuk. Pelabuhan atau bandar udara yang ditunjuk merupakan pelabuhan

\footnotetext{
21 Wawancara dengan Agus Tris, Bagian Penindakan dan Penyidikan (P2) Kantor Pengawasan dan Pelayanan Bea dan Cukai (KPPBC) Tipe Madya Pabean B Kota Tanjungpinang, Hari Senin, Tanggal 20 Maret 2017.

22 Wawancara dengan Dedy Kurniawan, Bagian Kepabeanan dan Cukai Kantor Pengawasan dan Pelayanan Bea dan Cukai (KPPBC) Tipe Madya Pabean B Kota Tanjungpinang, Hari Rabu, Tanggal 21 Februari 2018.

23 Rico Nandra Pratama, Gunawan Jatmiko, and Damanhuri Warganegara, "Peranan Penyidik Pegawai Negeri Sipil Bea Cukai dalam Pencegahan Tindak Pidana Penyelundupan Rokok Via Tol Laut," Jurnal Bagian Hukum Pidana Poenale, Vol. 6, No. 4 (2018), hlm. 10.
} 
atau bandar udara yang telah mendapatkan izin dari Menteri Perhubungan dan telah mendapatkan penetapan. ${ }^{24}$

Pemasukan dan pengeluaran barang ke dan dari Kawasan Bebas Kota Tanjungpinang selama ini masih memakai pelabuhan bebas yang berada di Kawasan Bebas Kabupeten Bintan berdasarkan Keputusan Menteri Perhubungan Nomor : KP-25 Tahun 2009 Tentang Penetapan Pelabuhan Bebas Pada Kawasan Perdagangan Bebas Di Batam, Bintan Dan Karimun, yaitu:

a) Pelabuhan Sei Kolak Kijang di Kecamatan Bintan Timur;

b) Pelabuhan Tanjung Uban di Kecamatan Bintan Utara;

c) Pelabuhan Seri Udana, Lobam di Kecamatan Bintan Utara.

Membentuk pelabuhan bebas untuk kawasan bebas Kota Tanjungpinang sudah direncanakan dan dalam pembangunan, yaitu Pelabuhan Moco di Dompak sebagai pelabuhan bongkar muat kontainer di kawasan bebas Kota Tanjungpinang, namun pembangunannya belum saat ini belum selesai. ${ }^{25}$

b. Belum adanya Pos Penjagaan khusus untuk mengawasi batas-batas zona kawasan bebas dengan daerah lain dalam pabean

Untuk kepentingan pengawasan perlu ditetapkan Pos Pengawasan Pabean untuk mengawasi pemasukan dan pengeluaran barang khusus kawasan bebas dan ini semestinya sudah menjadi tanggungjawab badan pengusahan kawasan Wilayah Kota Tanjungpinang. ${ }^{26}$

Kebijakan Kawasan Perdagangan dan Pelabuhan Bebas dengan semangat yang bertujuan untuk kemajuan industri dan perekonomian wilayah memiliki hal yang kontradiktif dengan kharakteristik Barang kena cukai yang pada hakikatnya penggunaan barang tersebut berdampak negatif dan perlu pembatasan dalam

\footnotetext{
${ }^{24}$ Pasal 2 ayat (2) dan (3) Peraturan Pemerintah Republik Indonesia Nomor 10 Tahun 2012 Tentang Perlakuan Kepabeanan, Perpajakan, Dan Cukai Serta Tata Laksana Pemasukan Dan Pengeluaran Barang Ke Dan Dari Serta Berada Di Kawasan Yang Telah Ditetapkan Sebagai Kawasan Perdagangan Bebas Dan Pelabuhan Bebas.

25 Wawancara dengan Pamri, Anggota 1 Bidang Administrasi dan Penyusunan Program Badan Pengusahaan Kawasan Perdagangan Bebas Dan Pelabuhan Bebas Bintan Wilayah Kota Tanjungpinang, Hari Senin, Tanggal 12 Februari 2018.

26 Wawancara dengan Terry, Bagian Penindakan dan Penyidikan (P2) Kantor Pengawasan dan Pelayanan Bea dan Cukai (KPPBC) Tipe Madya Pabean B Kota Tanjungpinang, Hari Senin, Tanggal 5 Maret 2018.
} 
penggunaannya. ${ }^{27}$ Sebaiknya barang kena cukai untuk kebutuhan penduduk kawasan bebas dipertimbangkan lagi, untuk apa dibebaskan kalau bersifat merusak namun pengecualian ini boleh saja apabila diperlakukan untuk daerah pariwisata sebagai pendorong kemajuan pariwisata. ${ }^{28}$

Pada hakekatnya hukum merupakan salah satu produk manusia dalam membangun dunianya, yang bisa dicermati atau ditelaah melalui interaksi yang berlangsung dimasyarakat. Dalam artian, hukum itu dilahirkan oleh manusia dan untuk menjamin kepentingan dan hak-hak manusia itu sendiri. ${ }^{29}$ Tidak ditutup kemungkinan bahwa setiap produk-produk hukum baik seperti investasi, bisnis dan lainnya yang merupakan produk kepentingan manusia itu sendiri atau sekelompok manusia. ${ }^{30}$ Banyak dari kaidah-kaidah yang ditemukan atas dasar imperatif kategorik atau dengan kegunaan lain sebagai tujuan, hampir selalu manusia individual ikut diuntungkan dalam ikhtiar mewujudkan sesuatu yang juga merupakan kepentingan orang lain atau masyarakat. ${ }^{31}$

Undang-Undang Cukai, telah diatur mengenai perbuatan-perbuatan yang dikategorikan sebagai pelanggaran administrasi maupun perbuatan-perbuatan yang dikategorikan sebagai tindak pidana. Secara umum, pelanggaran dalam UndangUndang Cukai digolongkan sebagai Mala Prohibita atau Malum Prohibitum, yang berarti bahwa perbuatan tersebut tergolong sebagai kejahatan karena diatur demikian oleh Undang-Undang. Sebagai Mala prohibita, maka perbuatan tersebut harus dirumuskan secara jelas dalam Undang-Undang agar dapat dipahami dengan baik oleh masyarakat luas. ${ }^{32}$

Undang-Undang Nomor 39 tahun 2007 tentang perubahan atas UndangUndang Nomor 11 tahun 1995 tentang Cukai mengandung sanksi pidana dan sanksi tindakan dalam stesel sanksinya. Pasal yang mengatur sanksi pidana untuk tindak

\footnotetext{
27 Wawancara dengan Ari Mardhani, Kasubsi Intelijen Bagian Penindakan dan Penyidikan (P2) Kantor Pengawasan dan Pelayanan Bea dan Cukai (KPPBC) Tipe Madya Pabean B Kota Tanjungpinang, Hari Kamis, Tanggal 1 Maret 2018.

28 Wawancara dengan Nugroho Setiawan, Penyidik Pegawai Negeri Sipil (PPNS) Kantor Pengawasan dan Pelayanan Bea dan Cukai (KPPBC) Tipe Madya Pabean B Kota Tanjungpinang, Hari Kamis, Tanggal 1 Maret 2018.

${ }^{29}$ Sudjono Dirjosisworo, Sosiologi Hukum (Jakarta: Rajawali, 1983), hlm. 15.

30 Wawancara dengan Dedy Kurniawan, Bagian Kepabeanan dan Cukai Kantor Pengawasan dan Pelayanan Bea dan Cukai (KPPBC) Tipe Madya Pabean B Kota Tanjungpinang, Hari Rabu, Tanggal 21 Februari 2018.

31 J.J.H. Bruggink, terjemahan Arief Sidharta, Refleksi Tentang Hukum (Bandung: Citra Aditya Bakti, 1996), hlm. 244.

32 Indrawati and Bendito Menezes, "Penerapan Asas Ultimum Remidium dalam Penegakan Hukum Pidana di Bidang Cukai," Jurnal Cakrawala Hukum, Vol. 9, No. 1 (2018), hlm. 13.
} 
pidana Cukai diatur dalam Pasal 50 sampai dengan Pasal 58A yang berupa pidana penjara dan pidana denda. Sedangkan Pengaturan mengenai sanksi tindakan diatur dalam Pasal 7A sampai dengan 39 yang berupa izin Nomor Pokok Pengusaha Barang Kena Cukai dibekukan/dicabut dan sanksi administrasi berupa denda. ${ }^{33}$ Sehingga jika terjadi perbuatan yang telah dilarang dalam peraturan tersebut yang dilakukan oleh orang perseorangan maka sanksi pidana dapat di ancam kepadanya.

Penegakan hukum tindak pidana cukai terhadap barang kena cukai (rokok) di wilayah Kota Tanjungpinang belum ada yang sampai proses peradilan jikalau terjadi pelanggaran terhadap undang-undang cukai menerapkan sanksi administrasi berupa penegahan atau penyitaan dan terhadap barang tersebut dilaksanakan pemusnahan. ${ }^{34}$ Di dalam perkembangan hukum modern mengenal istilah double track system yang bermakna adanya pemisahan antara sanksi pidana dengan sanksi tindakan. Perkembangan sistem hukum inilah yang memperkenalkannya tindakan (maatregel) sebagai alternatif lain dari pidana pokok terutama pidana penjara. ${ }^{35}$ Sehingga sanksi yang diberikan Bea dan Cukai Tanjungpinang jika melihat dasar tersebut maka termasuk dari sanksi tindakan.

Tingkat praktis, perbedaan antara sanksi pidana dan sanksi tindakan agak samar, namun di tingkat ide dasar keduanya memiliki perbedaan fundamental. Keduanya bersumber dari ide dasar yang berbeda. Sanksi pidana bersumber pada ide dasar: "Mengapa diadakan pemidanaan?". Sedangkan sanksi tindakan bertolak dari ide dasar: "untuk apa diadakan pemidanaan itu?". Dengan kata lain, sanksi pidana sesungguhnya bersifat reaktif terhadap suatu perbuatan, sedangkan sanksi tindakan lebih bersifat antisifatif terhadap pelaku perbuatan tersebut. Jika fokus sanksi pidana tertuju pada perbuatan salah seseorang lewat pengenaan penderitaan (agar yang bersangkutan menjadi jera), maka fokus sanksi tindakan terarah pada upaya memberi pertolongan agar dia berubah. ${ }^{36}$

\footnotetext{
33 "Undang-Undang Nomor 39 Tahun 2007 Tentang Perubahan Atas Undang-Undang Nomor 11 Tahun 1995 Tentang Cukai," Lembaran Negara R. I Tahun 2007 Nomor 105, tambahan Lembaran Negara R.I Nomor 4755 34 Wawancara dengan Amiruddin, Kasubsi Inteligen Kantor Pengawasan dan Pelayanan Bea dan Cukai (KPPBC) Tipe Madya Pabean B Kota Tanjungpinang, Hari Kamis, Tanggal 17 September 2020.

35 Gita Santika Ramadhani, Barda Nawawi Arief, Purwoto, Sistem Pidana dan Tindakan "Double Track System" Dalam Hukum Pidana di Indonesia, Diponegoro Law Review, Volume 1, Nomor 4, Semarang: 2012, hlm. 2.

36 Sholehuddin, Sistem Sanksi Dalam Hukum Pidana Ide Dasar Double Track System \& Implementasinya, PT Rajagrafindo Persada, Jakarta: 2007, hlm. 31-32.
} 
Politik hukum pidana memandang hubungan sanksi dengan perbuatan adalah sebanding, menitikberatkan kepada akibat dari peredaran rokok ilegal tersebut jika di sandingkan oleh data dari Webinar virtual dikatakan oleh Ekonom Senior Indef Enny Sri Hartati bawah sesuai hasil simulasi yang Indef lakukan terkait penindakan rokok ilegal oleh Direktorat Jenderal Bea dan Cukai (DJBC) Kementerian Keuangan sepanjang 2020, terdapat kerugian negara yang mencapai triliunan rupiah. Disebutkan Enny, Bea Cukai mengklaim telah menindak peredaran rokok ilegal sebanyak 4 persen di tahun ini, dengan demikian negara mengalami kerugian sekitar Rp 5 triliun sampai akhir tahun 2020, belum terhitung pada tahun 2021. ${ }^{37}$ Maka dapat dilihat bahwa akibat dari perbuatan tersebut cukup memberi efek yang besar sehingga dalam pemberian sanksi tindakan harus memperhatikan beberapa hal yang menjadi satu kesatuan yaitu ketidaktahuan orang akan barang yang dilarang, jumlah barang dalam hitungan sedikit dan bukan merupakan pengulangan tindak pidana yang sama.

\section{PENUTUP}

\subsection{Simpulan}

Penegakan hukum tindak pidana cukai di perbatasan kawasan perdagangan bebas dan pelabuhan bebas bintan wilayah tanjungpinang masih menerapkan sanksi tindakan dimana barang-barang hasil tangkapan ditegah lalu di lakukan pemusnahan. Kebijakan kawasan perdagangan bebas dan pelabuhan bebas berimplikasi terhadap penegakan hukum tindak pidana cukai dikarenakan faktor yang terpenting adalah meletakkan sebagian wilayah Kota Tanjungpinang sebagai kawasan bebas sehingga akan sulit mengawasi lalu lintas barang tersebut serta terindikasi kuota rokok kawasan bebas tidak berimbang dengan jumlah penduduk dan kebutuhan yang wajar.

\subsection{Saran}

Pemberian kuota pembebasan cukai terhadap barang kena cukai jenis rokok untuk konsumsi masyarakat harus dijadikan pertimbangan terhadap urgensi hal tersebut.

37https://keprinews.co/20/03/2021/peredaran-rokok-ilegal-di-makin-subur-dinilai-kinerja-bea-cukaitanjungpinang-mandul/, Terakhir dikunjungi pada tanggal 15 Maret 2020, Jam 20.21WIB. 
Apakah pemberian kuota tersebut sejatinya menjadikan keuntungan dalam pengembangan tujuan dari kawasan perdagangan bebas dan pelabuhan bebas atau hanya merugikan negara baik dalam segi pendapatan negara atau kesehatan masyarakat serta terhadap perbuatan-perbuatan yang melanggar ketentuan dari perdagangan bebas dan pelabuhan bebas harus di pandang sebagai kejahatan namun satu sisi penyelesaian melalui sanksi tindakan sangat diperlukan tapi harus ada kategori tertentu yang diatur jelas sehingga sanksi pidana dapat di kesampingkan tanpa mengurangi tujuan hukum yaitu keadilan, kepastian dan kemanfataan.

\section{DAFTAR PUSTAKA}

\section{Buku-Buku}

Amiruddin, and Zainal Asikin. Pengantar Metode Penelitian Hukum. Jakarta: Raja Grafindo Persada, 2003.

Bruggink, J.J.H. Terjemahan Arief Sidharta. Refleksi Tentang Hukum. Bandung: Citra Aditya Bakti, 1996.

Dirjosisworo, Sudjono. Sosiologi Hukum. Jakarta: Rajawali, 1983.

Eddi Wibowo, dkk, Hukum dan Kebijakan Publik, Yayasan Pembaruan Administrasi Publik Indonesia, Yogyakarta: 2004.

Sholehuddin, Sistem Sanksi Dalam Hukum Pidana Ide Dasar Double Track System \& Implementasinya, PT Rajagrafindo Persada, Jakarta: 2007.

Soerjono Soekanto, Pendekatan Sosiologi Terhadap Hukum, Bina Aksara, Jakarta: 1987.

Sunggono, Bambang. Metode Penelitian Hukum. Jakarta: Raja Grafindo Persada, 2001.

Purnadi Purbacaraka, Penegakan Hukum Dalam Mensukseskan Pembangunan, Alumni, Bandung, 1977.

\section{Artikel Jurnal}

Anshori, Milyan Risydan Al. "Penguatan Bea Cukai Secara Kelembagaan Dalam Menghadapi Kejahatan Transnasional." Jurnal Ilmiah Dunia Hukum 1, no. 1 (2016): 45-60.

Gita Santika Ramadhani, Barda Nawawi Arief, Purwoto, Sistem Pidana dan Tindakan "Double Track System" Dalam Hukum Pidana di Indonesia, Diponegoro Law Review, Volume 1, Nomor 4, Semarang: 2012, hlm. 2.

Indrawati, and Bendito Menezes. "Penerapan Asas Ultimum Remidium Dalam 
Penegakan Hukum Pidana Di Bidang Cukai." Jurnal Cakrawala Hukum 9, no. 1 (2018): 11-20.

Pratama, Rico Nandra, Gunawan Jatmiko, and Damanhuri Warganegara. "Peranan Penyidik Pegawai Negeri Sipil Bea Cukai Dalam Pencegahan Tindak Pidana Penyelundupan Rokok Via Tol Laut." Jurnal Bagian Hukum Pidana Poenale 6, no. 4 (2018): 1-16.

Saroinsong, Jessica E. "Peran Penyidik Pegawai Negeri Sipil (PPNS) Dalam Tindak Pidana Bea Dan Cukai Menurut Undang-Undang No. 17 Tahun 2006 Tentang Kepabeanan Dalam Kasus Penyelundupan." Lex Et Societatis VII, no. 7 (2019): 33-42.

\section{Data Internet}

Kepri.antaranews.com. "Minuman Beralkohol Kawasan Bebas Beredar Di Tanjungpinang." Kepri.Antaranews.Com. Accessed November 21, 2017. https://kepri.antaranews.com/berita/16172/minuman-beralkohol-kawasanbebas-beredar-di-tanjungpinang, diakses pada tanggal 20 Maret 2017.

https://keprinews.co/20/03/2021/peredaran-rokok-ilegal-di-makin-subur-dinilaikinerja-bea-cukai-tanjungpinang-mandul/, diakses pada tanggal 15 Maret 2020.

\section{Peraturan Perundang-Undangan}

Undang-Undang Nomor 39 Tahun 2007 Tentang Perubahan Atas Undang-Undang Nomor 11 Tahun 1995 Tentang Cukai.

Peraturan Pemerintah Pengganti Undang-Undang Nomor 1 Tahun 2000 Tentang Kawasan Perdagangan Bebas Dan Pelabuhan Bebas.

Peraturan Pemerintah Pengganti Undang-Undang Republik Indonesia Nomor 1 Tahun 2007 Tentang Perubahan Atas Undang-Undang Nomor 36 Tahun 2000 Tentang Penetapan Peraturan Pemerintah Pengganti Undang-Undang Nomor 1 Tahun 2000 Tentang Kawasan Perdagangan Bebas Dan Pelabuhan Bebas Menjadi Undang-Undang.

Peraturan Pemerintah Republik Indonesia Nomor 41 Tahun 2017 Tentang Perubahan Atas Peraturan Pemerintah Nomor 47 Tahun 2007 Tentang Kawasan Perdagangan Bebas Dan Pelabuhan Bebas Bintan.

Peraturan Pemerintah Republik Indonesia Nomor 109 Tahun 2012 Tentang Pengamanan Bahan Yang Mengandung Zat Adiktif Berupa Produk Tembakau Bagi Kesehatan.

Peraturan Pemerintah Republik Indonesia Nomor 10 Tahun 2012 Tentang Perlakuan Kepabeanan, Perpajakan, Dan Cukai Serta Tata Laksana Pemasukan Dan Pengeluaran Barang Ke Dan Dari Serta Berada Di Kawasan Yang Telah Ditetapkan Sebagai Kawasan Perdagangan Bebas Dan Pelabuhan Bebas. 
Peraturan Menteri Keuangan Nomor 147/PMK.010/2016 Tentang Perubahan Ketiga Atas Peraturan Menteri Keuangan Nomor 179/PMK.011/2012 Tentang Tarif Cukai Hasil Tembakau, Lampiran I.

Peraturan Menteri Keuangan Republik Indonesia Nomor 47/PMK.04/2012 Tentang Tata Laksana Pemasukan Dan Pengeluaran Barang Ke Dan Dari Kawasan Yang Telah Ditetapkan Sebagai Kawasan Perdagangan Bebas Dan Pelabuhan Bebas Dan Pembebasan Cukai.

Peraturan Menteri Keuangan Republik Indonesia Nomor 120/PMK.04/2017 Tentang Perubahan Atas Peraturan Menteri Keuangan Nomor 47/PMK.04/2012 Tentang Tata Laksana Pemasukan Dan Pengeluaran Barang Ke Dan Dari Kawasan Yang Telah Ditetapkan Sebagai Kawasan Perdagangan Bebas Dan Pelabuhan Bebas Dan Pembebasan Cukai. 